\title{
COMMENT
}

\section{AMBIGUOUS ABANDON AND MURKY MALIGNANCY: CHARGING THE JURY ON IMPLIED MALICE}

If the circumstances attending a killing show an abandoned and malignant heart, a criminal homicide is murder in a number of American jurisdictions $;^{1}$ but charging this statutory standard to a jury without clarification often constitutes an unnoticed prejudicial error. People v. Phillips, ${ }^{2}$ currently on appeal to the California Supreme Court, illustrates the problem. The defendant chiropractor was convicted of second degree murder for the cancer death of a young girl. Allegedly because of his inducements, a scheduled operation which according to undisputed medical opinion was necessary to prolong her life was never performed. ${ }^{3}$ Because the jury was charged on felony murder, ${ }^{4}$ the district court on appeal reversed the conviction; but the court also stated that the defendant should be retried without the use of the felony murder rule and that the evidence presented at the first trial was ample to sustain a murder conviction.

The facts of this case demonstrate the unlikeliness that the defendant expressly intended to kill the girl. If there is a retrial, the jury charge on implied malice will therefore be crucial. ${ }^{5}$ Since part of California's statutory description of implied malice requires an "abandoned and malignant heart," " the charge will have to take these ambiguous words into account.

1 Aruz. Rev. Stat. Ann. \$13-451 (1956); Cal. Pen. Code \$188; Colo. Rev. Stat. AnN. \$ 40-2-3 (1953); Ga. Code ANN. \$26-1004 (1953); Idaho Code ANN. \$ 18-4002 (1948); Mont. Rev. Codes Ann. \$ 94-2502 (1947); Nev. Rev. Stat. $\$ 200.020$ (1963); UTAR CODE ANN. \$76-30-2 (1953). The Arkansas statute uses the words: "an abandoned and wicked disposition." ARR. STAt. AnN. \$41-2204 (1964). The New Mexico statute reads: "wicked and malignant heart." N.M. Stat. AnN. \$40A-2-2 (1953).

242 Cal. Rptr. 868 (Dist. Ct. App. 1965).

3 The parents testified that the defendant claimed he could cure the girl of cancer by building up her general condition and that he told them the hospital was an experimental place where their daughter would be used as a human guinea pig. Id. at 871 . It was undisputed that the defendant charged the parents $\$ 500$ in advance plus high prices for medicine on which he made a $100 \%$ profit. Id. at 873 .

4 The felony was grand theft-taking over $\$ 200$ from the parents by false pretenses. CAL. PEN. CODE $\$ \$ 484,487$. In holding that grand theft was not an inherently dangerous felony and that felony murder therefore did not apply, the court stated that it was unwilling to extend an "archaic and much criticized doctrine." 42 Cal. Rptr. at 879.

5 The case itself is a crucial one. The prosecution stated in its brief: "This is the first case of murder by false pretenses to reach an appellate court in the seven hundred years of recorded Anglo-American Law." 42 Cal. Rptr. at 875 n.7. A conviction here could lead to a substantial number of future convictions.

${ }^{6}$ Cal. Pen. Code $\S 188$. 
That past charges have not always dealt with them adequately is shown by the charge given at the first trial, whereby the jury was instructed to convict of second degree murder "if the circumstances proximately causing the killing show an abandoned and malignant heart . . . " 7 It is not improbable that jurors hearing a charge such as this will focus on "abandoned and malignant heart" and will associate the phrase with an evil disposition or hateful nature, thus believing that they should convict if the circumstances surrounding the killing show the defendant to be a despicable character. Upon first consideration this may appear to be a proper interpretation, but the facts of the Phillips case demonstrate the erroneous results to which it can lead. Assume that the judge gives the same charge on retrial and that the jurors give it this interpretation. Assume further that the jurors find that the defendant did not intend to kill the girl and that he thought his actions would be harmless and could not result in any further danger to her health. The jurors also find, however, that the defendant realized his treatment was useless; and they firmly believe that only a loathsome character would sell false hopes to the parents of a sick child. They therefore convict the defendant of murder.

A rule of law which makes criminality turn on whether the jurors greatly dislike ${ }^{8}$ the defendant does not give members of society a definite standard upon which to base their conduct. A defendant convicted under such a standard had no way of knowing that his behavior would be judged criminal; and the decision itself is a completely arbitrary one by the jury. ${ }^{9}$ Since jury charges phrased as the one given in the first trial of Phillips are susceptible to this legally unacceptable interpretation, they are prejudicial to the defendant; the defendant should therefore demand a more precise charge on this statutory description of implied malice. This Comment will be concerned with the form the requested charge should take.

The charge must be phrased in terms of the state of mind of the defendant. That this is the only relevant consideration is evident in the writings of the common-law commentators. Sir James Stephen was the first to distinguish clearly this category of implied malice. He described it as:

Knowledge that the act which causes death will probably cause the death of, or grievous bodily harm to, some person, whether

7- Cal. App. 2d at -, 42 Cal. Rptr. at 874. This charge substantially followed

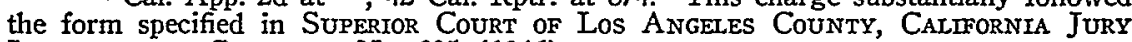
INSTRUCTIONS, CRIMINAL, No. 305 (1946).

8 Whether this dislike stemmed from an illegal act is irrelevant since the district court of appeal ruled felony murder out of the case.

${ }^{9}$ Cf. Screws v. United States, 325 U.S. 91, 149 (1945) (Roberts, J., dissenting) :

As misuse of the criminal machinery is one of the most potent and familiar instruments of arbitrary government, proper regard for the rational requirement of definiteness in criminal statutes is basic to civil liberties. As such it is included in the constitutional guarantee of due process of law. . . . To the same effect is Lanzetta v. New Jersey, 306 U.S. 451 (1939) (state statute making it criminal to be a "gangster" violative of due process). 
such person is the person actually killed or not, although such knowledge is accompanied by indifference whether death or grievous bodily harm is caused or not, or by a wish that it may not be caused ....10

Professors Michael and Wechsler have asserted that by this definition, "Stephen was giving such content to the general statement of earlier writers that 'malice' was 'implied' when the act was so reckless as to evince a 'heart regardless of social duty and fatally bent on mischief,' as he thought their illustrations and the few reported cases justified." 11 Holmes later incorporated the definition into The Common Law. ${ }^{12}$

When the common law was embodied in the criminal statutes of the various states, the legislatures which attempted specifically to describe this category of homicide (rather than to accept the common-law description through language such as "and all other murders . . ."13) used either the abandoned and malignant heart language or "an act imminently dangerous to others, and evincing a depraved mind, regardless of human life" 14 or a combination of the two. ${ }^{15}$ The latter phrase is the more prevalent ${ }^{16}$ and sets forth the standard in clearer language, embodying most of the qualities of Stephen's definition. Because of its common origin with the abandoned and malignant heart formulation, ${ }^{17}$ this phrase is a useful reference in attempting to clarify its ambiguity. Both the common law and this statutory description demonstrate that the requested charge must focus on the state of mind and emphasize the knowledge of danger and disregard for life.

The conclusion that the above are the relevant considerations is buttressed by the opinions of contemporary authorities. Current writers on the criminal law describe the implied malice category of murder in terms similar to those of Stephen, and decry the ambiguity of the statutory descriptions. ${ }^{18}$ In the Model Penal Code the abandoned and malignant heart standard is replaced by a category encompassing all homicides com-

10 Stephen, A Digest of the Crimrnal Law art. 223 (4th ed. 1887). (1940).

11 Michael \& Wechsler, Criminal LaW and Its Administratton $195 \mathrm{n} .2$

12 Holares, The Common Law 44 (Howe ed. 1963).

13 See, e.g., PA. Stat. AnN. tit. 18, $\$ 4701$ (1963):

All murder which shall be perpetrated by means of lying in wait, or by any other kind of willful, deliberate and premeditated killing, or which shall be committed in the perpetration of, or attempting to perpetrate any arson, rape, robbery, burglary, or kidnapping, shall be murder in the first degree. All other kinds of murder shall be murder in the second degree. . . . 14 E.g., N.Y. PEN. Law \$ 1044.

15 The statutes are collected and discussed in Moreland, The Law of Homicioe 213-16 (1952).

16 See $i d$. at 213-14.

17 "All the statutes in effect in the twenty-two jurisdictions which have attempted to describe the type of actor and the conduct required in the case of the negligent murder are attempted codifications of the common law." Id. at 215.

18 Id. at 215-16; Perkins, Criminal Law 679 (1957). 
mitted "recklessly under circumstances manifesting extreme indifference to the value of human life." 19

Of course, the most authoritative reference in the search for a correct charge on the abandoned and malignant heart standard would be statements by the appellate courts as to what constitutes an acceptable charge. Unfortunately, the courts rarely speak to this specific problem. There is, however, some evidence that courts speak of the standard in terms of the legally relevant factors. In Mayes v. People the Supreme Court of Illinois explained:

So, here, it was utterly immaterial whether plaintiff in error intended the glass should strike his wife, his mother-in-law, or his child, or whether he had any specific intent, but acted solely from general malicious recklessness, disregarding any and all consequences. It is sufficient that he manifested a reckless, murderous disposition,- -in the language of the old books, "A heart void of social duty, and fatally bent on mischief." 20

It is also significant that research has revealed no cases in abandoned and malignant heart jurisdictions which specifically reject a requested jury charge in terms similar to those set forth by Stephen.

Now that the particular state of mind to be described in the requested charge has been determined, it remains to enumerate those factors which best indicate that state of mind. A state of mind characterized by a knowledge of danger and disregard for life can best be phrased in terms of the defendant's awareness ${ }^{21}$ of an unjustifiably high probability that death or grievous bodily harm will result from his behavior. Pinpointing such an unjustifiably high probability involves some difficult problems. The degree of probability necessary to make the defendant a murderer will vary in direct proportion to the social utility of the behavior causing death. This is because some acts are so useful to society in general or to certain individuals in particular that the benefit which they yield as a class outweighs the danger they create. ${ }^{22}$ In the Phillips case the parents might have been

19 Moder. Penal Code $\$ 210.2(1)$ (b) (Proposed Official Draft 1962).

20 Mayes v. People, 106 I11. 306, 313-14 (1883). Illinois has recently eliminated "abandoned and malignant heart" from its statutory description of murder. ILL. ANN. STAT. ch. 38, \&9-1 (Smith-Hurd 1964).

21 The problem of whether it is enough that the defendant should have been aware is considered at notes 26-32 infra and accompanying text.

22 Our society is not committed to preserving life at any cost. In its broadest sense, this rather unpleasant notion should be obvious. Wars are fought. The University of Mississippi is integrated. . . . Ventures are undertaken that, statistically at least, are certain to cost lives. Thus we build a tunnel under Mont Blanc because it is essential to the Common Market and cuts down the traveling time from Rome to Paris, though we know that about a man per kilometer of tunnel will die. We take planes and cars rather than safer, slower means of travel. And perhaps more telling, we use relatively safe equipment rather than the safest imaginable because-and it is not a bad reason-the safest costs too much.

Calabresi, The Decision for Accidents: An Approach to Nonfanlt Allocation of Costs, 78 HARv. L. REV. 713, 716 (1965). 
justified in consenting to an operation on their daughter even though there was a seventy percent chance that she would die during the operation; their consent would be justified on the ground that the operation would be of immense benefit if successful. ${ }^{23}$ Thus, the higher the degree of social utility in behavior, the higher the probability of death must be in order to convict of murder. ${ }^{24}$

Before this social utility can be incorporated into a jury charge, several clarifications are necessary. It must be realized that a risk to life can be justified by a utility which does not itself involve a preservation of life. When a passing pedestrian is killed by a falling girder at a downtown construction site, the builder is not prosecuted for murder, although he was aware of the great danger inherent in any such construction. This is because of the general consensus that the social utility of the completed structure is worth the risk. ${ }^{25}$ Secondly, social utility might justify a dangerous act even if the danger extends to the point where death is a certainty: an individual acts, knowing that his behavior is certain to cause death to one person, because the act is necessary to save ninety-nine persons who otherwise will also perish.

Before the jurors may consider social utility in determining whether the defendant was aware of an unjustifiably high probability of death, they must, under the suggested formulation, determine that the defendant actually believed that there was a socially useful objective to be achieved and that his behavior would be necessary to serve this utility. But must the jury also determine that these two beliefs of the defendant were reasonable? In considering this problem it is helpful first to assume a socially useful objective, and to determine whether the defendant's belief that his means were necessary to achieve this objective must be reasonable. Once this decision is made, it can be decided whether the defendant's belief that there is a socially useful objective must itself be reasonable.

The reason social utility is at all relevant in justifying great risk is that its presence voids the risk of that characteristic which makes it objectionable-indifference. It is this mental quality which makes an act murder, because a lack of concern as to whether one kills is morally so closely akin to an actual intent to kill. If a defendant takes a great risk

23 The surgeon, however, might not have been justified in independently making this decision. Whether taking a risk is acceptable also depends to some extent upon who makes the decision not merely on the amount of the risk coupled with the desirability of the result. Since we suppose parents to have a quantum of concern for the child far exceeding that which anyone like the surgeon, who stands in a mere professional relationship to her, could have, it is far more socially useful to entrust the decision solely to them.

24 The interaction of the probability of causing death and lack of social utility can be seen in a series of five hypothetical situations. In all five a man drives past an unfenced school playground, the location of which he is aware, at seventy miles per hour. One should consider whether the following destinations affect his culpability: a party, before the refreshments are gone; a business meeting, to clinch a deal; the school, he is a teacher and late; a fire, he is a fireman; the hospital, before his son dies from a bleeding wound.

25 See note 22 supra. 
because he believes his behavior necessary to a socially useful objective, he is striving for a goal valued highly by society and indifference is not present. This is so regardless of whether the defendant's belief that his means are necessary is reasonable. Therefore a bare belief in the necessity of one's means to an admittedly socially useful objective is sufficient to justify a risk of death.

The above argument will be unacceptable to those who hold a defendant to be aware of whatever a reasonable man in his position would have seen, even if lack of such awareness results in a murder conviction. They will contend that the defendant had an abandoned and malignant heart if a reasonable man would have been aware of a high probability of causing death or grievous bodily injury and if a reasonable man would have realized that his behavior would not effectuate a socially useful objective. Because of the profound effect that this reasonable man standard could have on the formulation of the requested charge, it is necessary at this point to consider the contentions of its adherents.

The cleavage between the reasonable man standard and the subjective standard (requiring an actual awareness by the defendant) can be traced back to Holmes and Stephen, the former advocating the reasonable man standard. ${ }^{26}$ While the reasonable man standard is the law in England, ${ }^{27}$ many American courts deal with the problem ambiguously ; ${ }^{28}$ and, without a clear charge, it is impossible to tell which standard the jury is using.

The strongest arguments for the reasonable man standard are practical ones. Realizing that in most cases where the defendant does not have the awareness of the reasonable man, drunkenness is the cause, Professor Moreland argues:

$26 \mathrm{Mr}$. Justice Holmes often espoused his viewpoint from the bench, e.g., Commonwealth v. Pierce, 138 Mass. 165, 178 (1884) (dictum) :

The very meaning of the fiction of implied malice in such cases at common

law was, that a man might have to answer with his life for consequences which he neither intended nor foresaw. To say that he was presumed to have intended them, is merely to adopt another fiction, and to disguise the truth. The truth was, that his failure or inability to predict them was immaterial, if, under the circumstances known to him, the court or jury, as the case might be, thought them obvious.

Professors Michael and Wechsler, in speaking of Justice Holmes' position, have said: "Whether the common law judges carried the law of murder so far along the line of externality must be doubted. Stephen believed, as we have said, that the actor must have knowledge of the danger and not merely of the circumstances." MrchaEI $\&$ WECHSLER, op. cit. supra note 11, at 196. Stephen's position can be seen in his definition in text accompanying note 10 supra.

27 Director of Public Prosecutions v. Smith, [1960] 3 All E.R. 161 (H.L.). Smith was severely criticised by Williams, Constructive Malice Revived, 23 MODERN L. REV. 605 (1960).

28 MICHAEL \& WECHSLER, op. cit. sipra note 11, at 198; Moreland, op. cit. supra note 15 , at 39 . While agreeing that the cases are not unambiguous, Professor Collings attempts to separate cases using a subjective standard from those using the reasonable man test. Collings, Negligent Murder-Some Stateside Footnotes to Director of Public Prosecutions v. Snith, 49 CAlIF. L. REv. 254 (1961). 
[I]t is apparent that courts, as well as juries, in this country show an unwillingness to allow drunkenness to afford immunity to a conviction for negligent murder if the conduct of the accused is so extremely dangerous and highly barbarous as to warrant a conviction. If courts and juries are going to reach this result regardless of legal technicalities, it would seem better to follow the view of Holmes and frankly hold the defendant guilty because his conduct is barbarous rather than to follow Stephen's view and reach the same result by interpreting the facts so as to find knowledge of the danger, although it may not actually exist. ${ }^{29}$

The difficulty with this approach is that it does not face the problem on its merits but, rather, abdicates to those who are unwilling to follow the law. A more persuasive argument for the reasonable man standard is that there are more degrees of criminal negligence than there are available penalties, so that murder (at least in the second degree) should include extremely gross negligence. Admitting the problem, the question remains whether the needed extra penalty is the murder penalty.

A final argument for negligent murder is that the subjective standard puts too difficult a burden upon the prosecution; it is impossible to prove by direct evidence what knowledge a defendant had at the time of the offense. However, the burden of proof under the subjective standard can be greatly alleviated and the question can be put lucidly to the jury through the judicious use of the reasonable man standard, not as an unassailable implication, but rather as a rebuttable presumption. ${ }^{30}$

It is significant that most modern commentators on the criminal law favor the subjective standard. ${ }^{31}$ Murder never included all criminal homicides, but was set apart for those killers actuated by malice aforethought. The burden seems to be on the adherents of the reasonable man standard to reconcile this malice with negligence. It has already been demonstrated that the particular category of murder which evolved into the abandoned and malignant heart standard was intended for those defendants with a particular state of mind characterized by indifference. This

29 MoReland, op. cit. supra note 15 , at 40.

30 See the following jury charge:

In order to convict, you must find that the defendant knew that his act was

likely to cause death or serious bodily injury to another. Knowledge is a mental state and as such often remains hidden in the mind and is rarely capable of proof by direct evidence. It must be inferred from outward manifestations, or words or acts of the defendant, or from facts and circumstances known to him at the time of his act. You can find that the defendant knew that his act was likely to cause death or serious bodily harm if a reasonable person in his situation would have known of the danger, unless you also find that the defendant for some reason was not aware of the risk.

Collings, supra note 28, at 293.

31 Professor Collings lists Stephen, J. W. C. Turner, Glanville Williams, Jerome Hall, Professors Wechsler and Michael, and the Royal Commission on Capital Punishment as favoring the subjective standard. Collings, supra note 28, at 268. Professor Moreland, on the other hand, favors the reasonable man standard. MoRELAND, $o p$. cit. supra note 15 , at 40 . 
indifference becomes irrelevant under the reasonable man standard. Although the penalties for murder and other criminal homicides often overlap, there is value in maintaining an identifiable category having a more reprehensible label for those killers who intend to kill or who do not care whether they kill. Because of this label, murder has a greater deterrent effect than manslaughter; certainly this function is not furthered by including within the category a group which can be deterred only to a minor extent (assuming it is possible to deter negligence at all).

For the above reasons it is believed that negligent murder is unacceptable and that a bare belief by the defendant that his act is necessary to effectuate the socially useful objective is sufficient to justify a risk of death. ${ }^{32}$ Whether the defendant must be reasonable in his belief that the objective to be attained is socially useful involves other considerations. It was said that even an unreasonable belief that one's behavior is necessary to achieve a socially useful objective can justify a risk because the defendant's desire to attain a goal valued highly by society demonstrates that he is not indifferent to human life, but rather is striving for a goal which society feels is worth the risk. However, the same cannot be said for a defendant who unreasonably believes his objective to be socially useful. If the objective is not considered worth the risk by any reasonable man, the defendant is striving for a goal which cannot have much utility and is disregarding the risk to life which he is creating. He thus is indifferent to human life, or at least places it in low regard, since he values his socially useless objective more highly. That he thought his goal desirable cannot excuse him; to so hold would be to excuse almost all criminal conduct. It is arguable that he should be excused because he believed that society would agree with his value judgment. However, the extent to which a sane man's set of values is unreasonable is itself indicative of an indifference to society's values; it is the defendant possessing this unreasonable set of values which the abandoned and malignant heart standard is intended to punish.

Having established that which constitutes an unjustifiably high probability of death, the requested jury charge can now be drafted. Because of the danger inherent in their ambiguity, the words "abandoned and malig. nant heart" will not even be mentioned. ${ }^{33}$

The defendant is guilty of murder in the second degree . . . if you should find that he was aware of such an unjustifiably

32 For these same reasons the defendant cannot be convicted unless he is actually aware of an unjustifiably high probability of death; it is not enough that a reasonable man would have been aware.

33 An alternative would be to use qualifying language such as that used by Stephen in Regina v. Serné, 16 Cox Crim. Cas. 311, 312 (Central Crim. Ct. 1887):

[T] he words malice aforethought are technical. You must not, therefore, construe them or suppose that they can be construed by ordinary rules of language. The words have to be construed according to a long series of decided cases, which have given them meanings different from those which might be supposed. 
high probability of causing death or grievous bodily harm that he showed himself to be extremely indifferent to the value of human life. However, his acting in the face of a high probability of death is justified if he reasonably believed that there was an objective to be served which was so socially useful as to be worth the risk and if he had a bare belief that his behavior was necessary to serve that objective. If you find that the defendant was aware of a high probability of death and was not actuated by a purpose of sufficient social usefulness so that he showed himself to be extremely indifferent to the value of human life, you should return a verdict of second degree murder. The reason the law punishes such individuals as murderers is because their indifference is so closely akin to an actual intent to kill.

This Comment has attempted to demonstrate the prejudicial effect of a jury charge which includes the words "abandoned and malignant heart" and to offer an alternative charge replacing the harmful ambiguity with a clear statement of the legally relevant standard. On retrial the defendant in the Phillips case should object to the standard charge on abandoned and malignant heart which was given at the first trial on the ground that it permits the jurors to convict him of murder because he is a cancer quack and they therefore dislike him-a legally irrelevant consideration. Instead he should submit a charge similar to the above, the refusal of which would be prejudicial error. 